\title{
Isolation from Stevia rebaudiana of DMDP acetic acid, a novel iminosugar amino acid: synthesis and glycosidase inhibition profile of glycine and $\beta$-alanine pyrrolidine amino acids
}

\author{
R. Fernando Martínez ${ }^{1,2} \cdot$ Sarah F. Jenkinson ${ }^{1}$ (D - Shinpei Nakagawa ${ }^{3} \cdot$ Atsushi Kato $^{3} \cdot$ Mark R. Wormald $^{4}$. \\ George W. J. Fleet ${ }^{1}$. Jackie Hollinshead ${ }^{5}$. Robert J. Nash ${ }^{5}$
}

Received: 17 December 2018 / Accepted: 21 March 2019 / Published online: 11 May 2019

(C) The Author(s) 2019

\begin{abstract}
DMDP acetic acid [ $N$-carboxymethyl-2,5-dideoxy-2,5-imino-D-mannitol] 5 from Stevia rebaudiana is the first isolated natural amino acid derived from iminosugars bearing an $N$-alkyl acid side chain; it is clear from GCMS studies that such derivatives with acetic and propionic acids are common in a broad range of plants including mulberry, Baphia, and English bluebells, but that they are very difficult to purify. Reaction of unprotected pyrrolidine iminosugars with aqueous glyoxal gives the corresponding $N$-acetic acids in very high yield; Michael addition of both pyrrolidine and piperidine iminosugars and that of polyhydroxylated prolines to tert-butyl acrylate give the corresponding $N$-propionic acids in which the amino group of $\beta$-alanine is incorporated into the heterocyclic ring. These easy syntheses allow the identification of this new class of amino acid in plant extracts and provide pure samples for biological evaluation. DMDP $N$-acetic and propionic acids are potent $\alpha$-galactosidase inhibitors in contrast to potent $\beta$-galactosidase inhibition by DMDP.
\end{abstract}

Keywords Iminosugars $\cdot$ Amino acid $\cdot$ Stevia $\cdot \beta$-Galactosidase $\cdot \alpha$-Galactosidase $\cdot$ Hydroxy proline $\cdot$ Iminosugar acid $\cdot$ Sugar amino acids

\section{Introduction}

Many iminosugars, sugar mimics in which the ring oxygen of a pyranose or furanose is replaced by nitrogen to form polyhydroxylated pyrrolidines [e.g. DMDP

Handling Editor: W. Maison.

Electronic supplementary material The online version of this article (https://doi.org/10.1007/s00726-019-02730-5) contains supplementary material, which is available to authorized users.

Sarah F. Jenkinson

sarah.jenkinson@chem.ox.ac.uk

Atsushi Kato

kato@med.u-toyama.ac.jp

$\triangle$ George W. J. Fleet

george.fleet@chem.ox.ac.uk

$\triangle$ Robert J. Nash

robert.nash@phytoquest.co.uk

1 Chemistry Research Laboratory, 12 Mansfield Road, Oxford OX1 3TA, UK
(2,5-dideoxy-2,5-imino-D-mannitol) 1] and piperidines [e.g., DNJ (deoxynojirimycin) 2], have been isolated from plants (Fig. 1) (Asano et al. 2000; Watson et al. 2001). In contrast, 7a-epialexaflorine $\mathbf{3}$ from Alexa grandiflora (Pereira et al. 1991) and BR1 4 from Baphia racemosa (di Bello et al. 1984; Booth et al. 2007; Fleet et al. 1986, 1987; Manning et al. 1985) are among the very few corresponding iminosugar amino acids (Risseeuw et al. 2007, 2013) that have been identified as natural products. Sugar amino acids are much more difficult to isolate and identify

2 Departamento de Química Orgánica e Inorgánica, Facultad de Ciencias-UEX, IACYS-Unidad de Química Verde y Desarrollo Sostenible, 06006 Badajoz, Spain

3 Department of Hospital Pharmacy, University of Toyama, 2630 Sugitani, Toyama 930-0194, Japan

4 Glycobiology Institute, Department of Biochemistry, University of Oxford, Oxford OX1 3QU, UK

5 Phytoquest Limited, IBERS, Plas Gogerddan, Aberystwyth, SY23 3EB Ceredigion, Wales, UK 
<smiles>OC[C@H]1N[C@H](CO)[C@@H](O)[C@H]1O</smiles>

1<smiles>[R]N1C[C@H](O)[C@@H](O)[C@H]1CO</smiles>

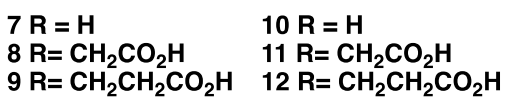<smiles>O=C(O)C1[C@H](O)C(O)[C@@H]2[C@H](O)CCN12</smiles>

3<smiles>[R]N1[C@H](C(=O)O)[C@@H](O)C(O)[C@H]1C</smiles>

$13 \mathrm{R}=\mathrm{H}$

$14 \mathrm{R}=\mathrm{CH}_{2} \mathrm{CO}_{2} \mathrm{H}$ $15 \mathrm{R}=\mathrm{CH}_{2} \mathrm{CH}_{2} \mathrm{CO}_{2} \mathrm{H}$

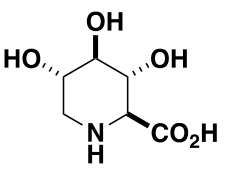

4

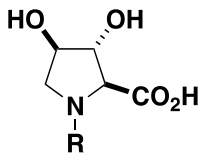

$16 \mathrm{R}=\mathrm{H}$

$17 \mathrm{R}=\mathrm{CH}_{2} \mathrm{CO}_{2} \mathrm{H}$

$18 \mathrm{R}=\mathrm{CH}_{2} \mathrm{CH}_{2} \mathrm{CO}_{2} \mathrm{H}$<smiles>O=C(O)CN1C(CO)[C@H](O)C(O)[C@H]1CO</smiles>

5

形 $20 \mathrm{R}=\mathrm{CH}_{2} \mathrm{CH}_{2} \mathrm{CO}_{2} \mathrm{H}$<smiles>C[C@@H]1C(O)[C@H](O)C(CO)N1CCC(=O)O</smiles>

6<smiles>C[C@@H]1CCCC2C(O)C(O)[C@@H](C)N21</smiles>

21

Fig. 1 Structure of iminosugars and sugar amino acids

than their iminosugar analogues due to the high content of acidic and neutral amino acids in plants. DMDP 1 is the most widely occurring iminosugar; GCMS studies on a number of diverse plant extracts from Stevia rebaudiana, mulberry, and bluebell (Hyacinthoides non scripta) show that $N$-alkylated amino acids such as DMDP acetic 5 and DMDP propionic $\mathbf{6}$ acids are present (Gallagher and Yu 2014; Nash et al. 2018; Wilson et al. 2010). This paper describes (a) the isolation of DMDP acetic acid $\mathbf{5}$ from Stevia in which the amino group of glycine is incorporated into the hydroxylated pyrrolidine ring, (b) the efficient conversion of the unprotected pyrrolidine iminosugars DMDP 1, DAB [1,5-dideoxy1,5-imino-D-arabinitol] 7 and galacto-DMDP [2,5-dideoxy2,5-iminogalactitol] 10 to pyrrolidine acetic acids 5, 8, and 11 by treatment with aqueous glyoxal, (c) Michael addition of unprotected pyrrolidine 5, 7, 10 and piperidine DNJ 2 iminosugars and the sugar amino acids $\mathbf{1 3}$ and $\mathbf{1 6}$ to tertbutyl acrylate to give $N$-propionic acid derivatives in which the amine of $\beta$-alanine is incorporated into the heterocyclic ring, and (d) the effect of the $N$-glycine and $N$ - $\beta$-alanine sidechains on glycosidase inhibition, in particular on the change in $\alpha$ - and $\beta$-galactosidase activity.

\section{Results and discussion}

\section{Isolation of DMDP acetic acid 5 from Stevia rebaudiana}

Steviamine 21, [with the same relative pyrrolidine ring stereochemistry as galacto-DMDP 10] was the first alkaloid isolated from Stevia (Michalik et al. 2010; Thompson et al. 2009) and has shown potential anti-metastatic activity by inhibiting the hexosaminidase released by a breast cancer cell line (Ramessur et al. 2010). A number of intensely sweet glycosides of steviol are widely available commercially; yet, the iminosugars of Stevia are hitherto unreported despite their strong biological activity. The iminosugar content can be as high as $0.5 \%$ of stevia leaves and comprises mainly DMDP 1; some $2 \mathrm{~g}$ of DMDP along with $50 \mathrm{mg}$ of DMDP acetic acid 5 were isolated from $2.2 \mathrm{~kg}$ of leaves from Stevia rebaudiana Betoni (Asteraceae), a herb native to South America. Many plants containing iminosugars also contain their $N$-acetic and $N$-propionic acids which have so far evaded identification and isolation due to the complex free amino acid profile of most plants (Bell 1976).

\section{Synthesis of pyrrolidine $\mathrm{N}$-acetic acids from unpro- tected iminosugars}

Easy syntheses of $N$-alkylated amino acids allow the identification of natural products in crude extracts from plants where isolation of the pure natural product is difficult. Although the mechanism is unclear (Amadori or intramolecular Cannizarro rearrangements), the reaction of secondary amines with aqueous glyoxal gives $N, N$-dialkyl glycines in good yield (Scheme 1) (Farfán et al. 1987). Treatment of the iminosugars DMDP 1, DAB 7, and galacto-DMDP 10 with aqueous glyoxal at $70{ }^{\circ} \mathrm{C}$ for $14-17 \mathrm{~h}$ gave the corresponding acetic acids $\mathbf{5}, \mathbf{8}$, and $\mathbf{1 1}$ in yields of $100 \%, 82 \%$, and $99 \%$, respectively, and were readily isolated with a minimum of purification. This transformation was unsuccessful when applied to hydroxylated prolines [the monocyclic equivalent of epialexaflorine $\mathbf{1 3}$ and the dihydroxyproline 16]; the acetic acids 14 and 17 were not isolated. Surprisingly, the piperidine iminosugar DNJ 2 with glyoxal under the same conditions gave a complex reaction mixture and did not allow the isolation of DNJ acetic acid 19. 
Scheme 1 Reagents and conditions: (i) $(\mathrm{CHO})_{2}, \mathrm{H}_{2} \mathrm{O}, 70{ }^{\circ} \mathrm{C}$, $14-17 \mathrm{~h}$<smiles>O=C(O)C[C@H]1[C@@H](O)[C@@H](O)[C@@H](CO)N1CCO</smiles>

5

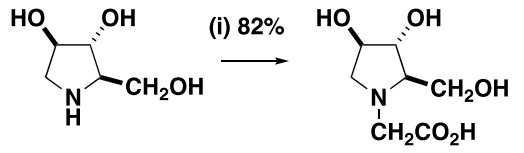

8<smiles>O=C(O)CN1C(CO)C(O)C(O)C1CO</smiles>

10

11

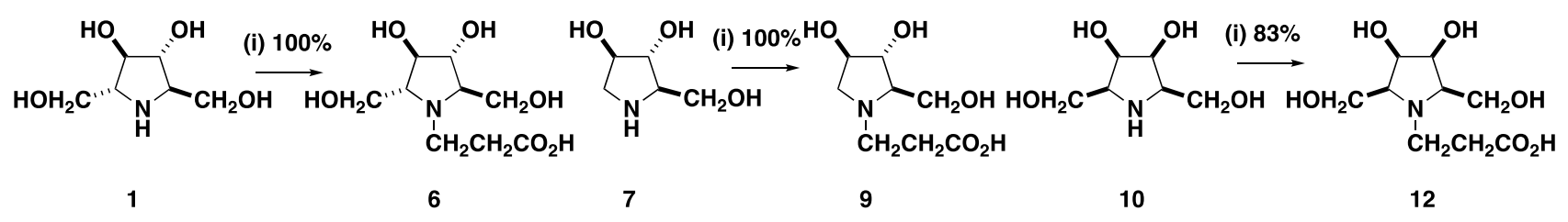

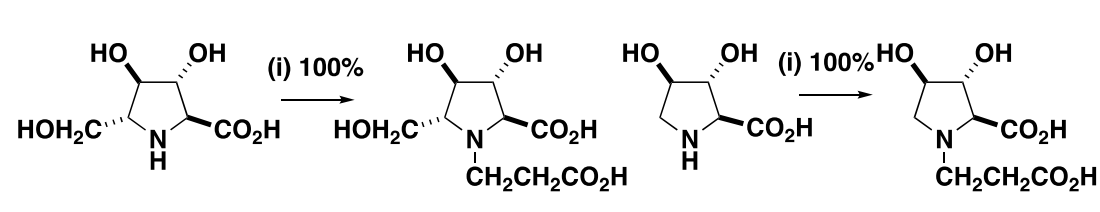

13

15

16

18<smiles>OC[C@H]1NC[C@@H](O)C(O)[C@H]1O</smiles>

2

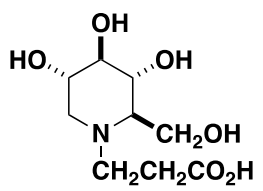

20

Scheme 2 Reagents and conditions: (i) $\mathrm{CH}_{2}=\mathrm{CHCOO}^{\mathrm{t}} \mathrm{Bu}, \mathrm{MeOH}, 50^{\circ} \mathrm{C}, 48 \mathrm{~h} ; \mathrm{CF}_{3} \mathrm{CO}_{2} \mathrm{H}, \mathrm{H}_{2} \mathrm{O}, \mathrm{rt}, 48 \mathrm{~h}$

\section{Synthesis of pyrrolidine and piperidine $N$-propionic acids from unprotected iminosugars and polyhy- droxylated amino acids}

The Michael addition of unprotected polyhydroxylated prolines, and pyrrolidine and piperidine iminosugars, with tertbutyl acrylate in the presence of methanol (to avoid polymerization of the acrylate) at $50{ }^{\circ} \mathrm{C}$, followed by hydrolysis with aqueous trifluoroacetic acid, gave consistent excellent yields of $\beta$-alanine analogues in which the amine formed part of a pyrrolidine or piperidine ring (Scheme 2). Minimal purification was necessary. The pyrrolidine iminosugars DMDP 1, DAB 7 and galacto-DMDP 10 gave the $N$-propionic acids $\mathbf{6}(100 \%), \mathbf{9}(100 \%)$, and $\mathbf{1 2}$ (83\%). The hydroxyprolines $\mathbf{1 3}$ and $\mathbf{1 6}$ formed 15 and $\mathbf{1 8}$ in quantitative yield; the structure of $\mathbf{1 5}$ was unequivocally confirmed by X-ray diffraction (Edgeley et al. 2012). DNJ 2 produced DNJ-propionic acid $\mathbf{2 0}$ in $99 \%$ yield.

\section{Glycosidase inhibition}

The glycosidase inhibition profiles of a number of $\mathrm{N}$-acetic and $\mathrm{N}$-propionic acids were compared with their parent iminosugars and prolines (Table 1). DMDP 1 showed potent inhibitions of bovine liver $\beta$-glucosidase and $\beta$-galactosidase with $\mathrm{IC}_{50}$ values of 9.7 and $3.3 \mu \mathrm{M}$, respectively (Best et al.
2010); 1 also showed weak and broad inhibition against $\alpha$-glucosidase, $\beta$-mannosidase, trehalase, and amyloglucosidase. Both DMDP acetic 5 and DMDP propionic 6 acids showed significantly weaker $\beta$-glucosidase and $\beta$-galactosidase inhibition, but both were good inhibitors of $\alpha$-galactosidase with $\mathrm{IC}_{50}$ value of $35 \mu \mathrm{M}$ and $67 \mu \mathrm{M}$, respectively; this is the first report of good $\alpha$-galactosidase inhibition by DMDP derivatives. $N$-Ethyl and $N$-propyl derivatives of DMDP did not show such changes in their glycosidase inhibition profile (Asano et al. 1995). galactoDMDP 10 is a potent and specific inhibitor of coffee bean $\alpha$-galactosidase $\left(\mathrm{IC}_{50} 0.19 \mu \mathrm{M}\right)$ (Ayers et al. 2012), but had no inhibition of $\beta$-galactosidase. The corresponding acetic $\mathbf{1 1}$ and propionic $\mathbf{1 2}$ acids remain potent inhibitors of $\alpha$-galactosidase, but showed no significant inhibition of $\beta$-galactosidase. galacto-DMDP propionic acid $\mathbf{1 2}$ was a highly selective $\alpha$-galactosidase inhibitor. These results indicated that $\mathrm{COOH}$ group of the $N$-terminal chain caused selective and potent $\alpha$-galactosidase inhibitions. DAB 7, related to DMDP 1 by the loss of a hydroxymethyl group, is a good inhibitor of some $\alpha$-glucosidases, but does not have any effect on galactosidases; both DAB acetic $\mathbf{8}$ and propionic 9 acids were significantly weaker glucosidase inhibitors and did not show any $\alpha$-galactosidase inhibition. Neither of the propionic acids $\mathbf{1 5}$ or $\mathbf{1 8}$ derived from the 
Table 1 Concentration of iminosugar pyrrolidine carboxylic acids giving 50\% inhibition of various glycosidases

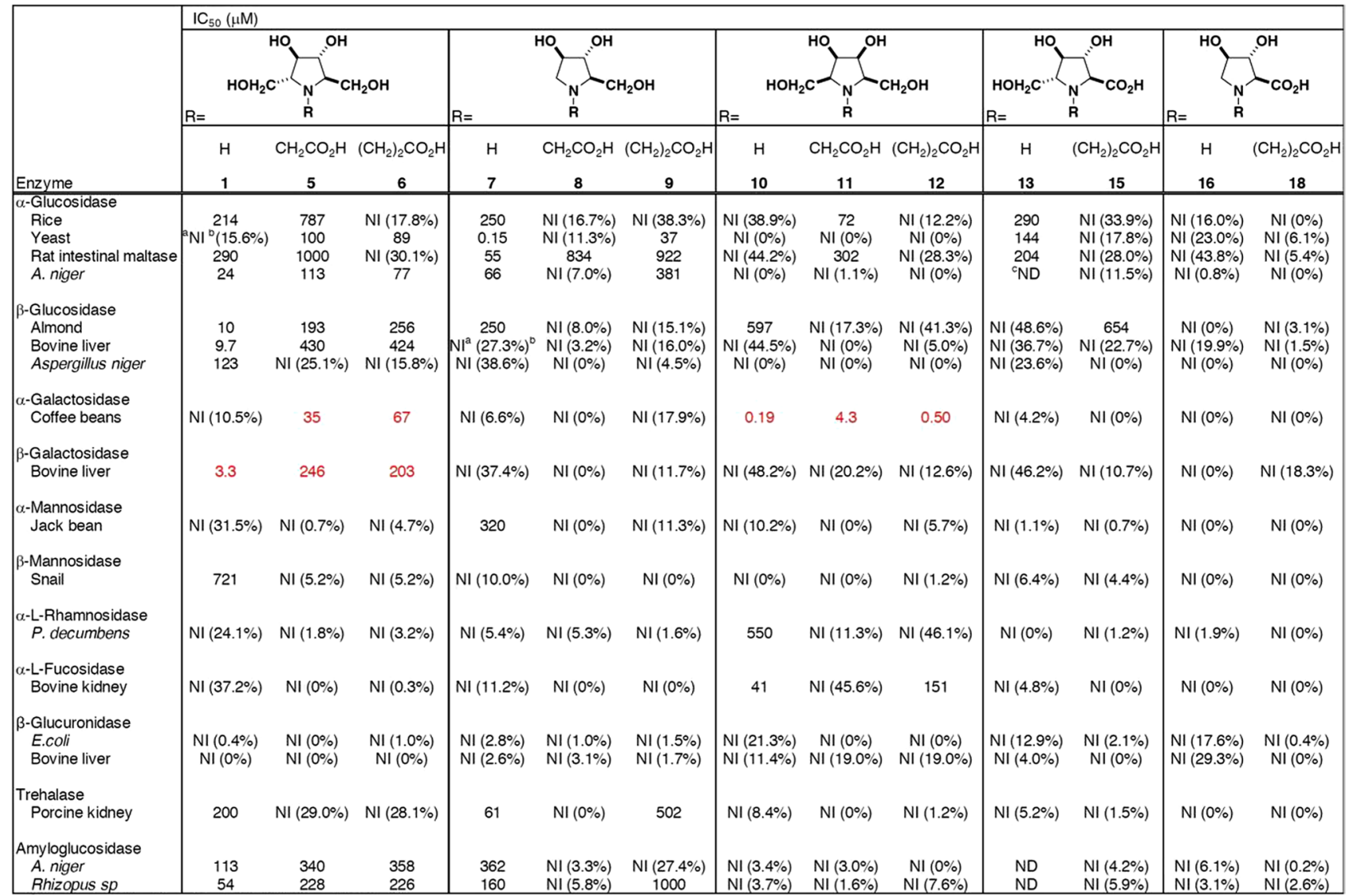

${ }^{\mathrm{a}} N I$ no inhibition (less than $50 \%$ inhibition at $1000 \mu \mathrm{M}$ )

b ( ): inhibition \% at $1000 \mu \mathrm{M}$

${ }^{\mathrm{c}} N D$ not determined

polyhydroxylated prolines $\mathbf{1 3}$ and $\mathbf{1 6}$ showed inhibition of any glycosidases.

\section{Experimental}

All commercial reagents were used as supplied. Methanol was purchased dry from Alfa Aesar in sure-seal bottles. All other solvents were used as supplied (Analytical or HPLC grade), without prior purification. Melting points were recorded on a Kofler hot block and are uncorrected. Optical rotations were recorded on a Perkin-Elmer 241 polarimeter with a path length of $1 \mathrm{dm}$. Concentrations are quoted in $\mathrm{g}$ $100 \mathrm{~mL}^{-1}$. Infrared spectra were recorded on a Perkin-Elmer 1750 IR Fourier Transform spectrophotometer using thin films on a diamond ATR surface (thin film). Only the characteristic peaks are quoted. Low-resolution mass spectra $(\mathrm{m} / \mathrm{z})$ were recorded on an Agilent 6120 spectrometer and highresolution mass spectra (HRMS $\mathrm{m} / \mathrm{z}$ ) on a Bruker microTOF mass analyzer using electrospray ionization (ESI). Nuclear magnetic resonance (NMR) spectra were recorded on Bruker
AVIII 400 HD nanobay and Bruker DQX 400 spectrometers $\left({ }^{1} \mathrm{H}: 400 \mathrm{MHz}\right.$ and $\left.{ }^{13} \mathrm{C}: 100.6 \mathrm{MHz}\right)$ in the deuterated solvent stated. All chemical shifts $(\delta)$ are quoted in ppm and coupling constants $(J)$ in Hz. Residual signals from the solvents were used as an internal reference, except in the case of deuterium oxide, where acetonitrile was used as the reference. The syntheses of all $\mathrm{N}$-alkyl derivatives were carried out directly from their unprotected parent iminosugars and amino acids as previously prepared: 2,5-dideoxy-2,5-imino-D-mannitol (DMDP) 1 (Best et al. 2010), 2,5-dideoxy2,5-imino-D-mannonic acid [(3S)-3-hydroxy-bulgecinine] 13 (Best et al. 2010), and deoxynojirimycin (DNJ) 2 (Best et al. 2010) and 2,5-dideoxy-2,5-iminogalactitol (galacto-DMDP) 10 from glucuronolactone (Ayers et al. 2012), 1,4-dideoxy1,4-imino-D-arabinitol (DAB) 7 and trans,trans-dihydroxyproline 16 from diacetone glucose (Fleet and Witty 1990). 


\section{Isolation of DMDP acetic acid 5 and DMDP 1 from Stevia}

Leaves of commercially supplied $S$. rebaudiana Betoni (Asteraceae), a herb native to South America, were used for the isolation of DMDP acetic acid 5. Stevia leaf $(2.2 \mathrm{~kg})$ was obtained from Cotswold Health Products UK (batch 060621) and extracted in water for $15 \mathrm{~h}$. The filtrate was applied to a cation exchange column (Amberlite IR120) in the $\mathrm{H}^{+}$form and washed with water, and then the amino acids and SAA displaced with $2 \mathrm{M}$ ammonia solution. After removal of the ammonia under reduced pressure at $40{ }^{\circ} \mathrm{C}$, the material was applied to anion exchange resin (Amberlite CG400 OH- form) and washed with water to give an unretained fraction containing DMDP 1 and the neutral and acidic compounds displaced with $1 \mathrm{M}$ acetic acid. Both fractions were reduced in volume at reduced pressure and the DMDP purified using Amberlite CG50 resin in the ammonia form with 20 water fractions collected. The DMDP acetic acid 5 was purified from other amino acids by applying the CG400 retained fraction back on the CG400 in the acetate form and 20 fractions collected with water. Analysis of fractions was by GCMS of the trimethylsilylation of aliquots of the fractions. DMDP 1 gives a distinctive EI fragmentation with major ions 217 (100\%), $258(50 \%)$, and $348(80 \%)$ $436 \mathrm{M}+-15$ (methyl) (2\%) amu (retention time $8.7 \mathrm{~min}$ ) and the DMDP acetic acid 5 with retention time $10.8 \mathrm{~min}$ has ions 147 (100\%), $298(50 \%)$, and $478(80 \%), 566 \mathrm{M}+$ -15 (methyl) (2\%) amu. Mannitol as reference on the same mid-polarity column has a retention time of $10.5 \mathrm{~min}$. Yields were: DMDP 1 (2 g) and DMDP acetic acid $5(50 \mathrm{mg})$. The GCMS and NMR spectra of DMDP 1 and DMDP acetic acid 5 were identical to those of the synthetic compounds in the paper.

\section{General procedure for pyrrolidine $\mathbf{N}$-acetic acids}

Glyoxal solution $(40 \% \mathrm{w} / \mathrm{w})$ in water $(1.1 \mathrm{eq})$ was added to a stirred solution of the corresponding iminosugar (1.0 eq) in water $(15 \mathrm{mg} / \mathrm{mL})$. The mixture was stirred at $70{ }^{\circ} \mathrm{C}$ for 14-17 h, after which the reaction mixture was concentrated in vacuo. The remaining residue was loaded onto a Dowex ion-exchange resin $\left(50 \mathrm{WX} 8, \mathrm{H}^{+}\right)$. The column was flushed with water and then eluted with $2 \mathrm{M}$ aqueous ammonia. The ammoniacal fraction was concentrated in vacuo to afford the corresponding compounds.

\section{$\mathrm{N}$-Carboxymethyl-2,5-dideoxy-2,5-imino-D-manni- tol 5}

DMDP 1 (20 mg, $0.12 \mathrm{mmol})$ gave DMDP acetic acid 5 $(27 \mathrm{mg}, 100 \%),[\alpha]_{\mathrm{D}}^{25}+5.9\left(c 0.15, \mathrm{H}_{2} \mathrm{O}\right) ; \nu_{\max }$ (thin film) $3235(\mathrm{OH}), 1614,1393(\mathrm{COO}) ; \delta_{\mathrm{H}}\left(\mathrm{D}_{2} \mathrm{O}, 400 \mathrm{MHz}\right) 3.77$
(2H, m, H-2 and $\mathrm{H}-5), 4.00\left(6 \mathrm{H}, \mathrm{m}, \mathrm{CH}_{2} \mathrm{~N}, \mathrm{H} 1\right.$ and $\left.\mathrm{H} 6\right)$, $4.23\left(2 \mathrm{H}, \mathrm{d}, J_{3,2} / J_{4,5} 5.6, \mathrm{H} 3\right.$ and $\left.\mathrm{H} 4\right) ; \delta_{\mathrm{C}}\left(\mathrm{D}_{2} \mathrm{O}, 100.6 \mathrm{MHz}\right)$ $52.8\left(\mathrm{CH}_{2} \mathrm{~N}\right), 57.2(\mathrm{C} 1$ and $\mathrm{C} 6), 70.5(\mathrm{C} 2$ and $\mathrm{C} 5), 74.8(\mathrm{C} 3$ and $\mathrm{C} 4), 171.3(\mathrm{C}=\mathrm{O}) ; \mathrm{m} / z\left(\mathrm{ESI}^{+}\right): 222\left([\mathrm{M}+\mathrm{H}]^{+}, 21 \%\right)$, $244\left([\mathrm{M}+\mathrm{Na}]^{+}, 100 \%\right)$; HRMS $\left(\mathrm{ESI}^{+}\right)$: found 244.0793 $\left([\mathrm{M}+\mathrm{Na}]^{+}\right) ; \mathrm{C}_{8} \mathrm{H}_{15} \mathrm{NNaO}_{6}$ requires 244.0792 .

\section{$\mathrm{N}$-Carboxymethyl-1,4-dideoxy-1,4-imino-D-arabi- nitol 8}

DAB $7(11 \mathrm{mg}, 0.08 \mathrm{mmol})$ gave $8(13 \mathrm{mg}, 82 \%)[\alpha]_{\mathrm{D}}^{25}$ $+20.7\left(c 0.47, \mathrm{H}_{2} \mathrm{O}\right) ; \nu_{\max }$ (thin film) $3234(\mathrm{OH}), 1614$, $1396(\mathrm{COO}) ; \delta_{\mathrm{H}}\left(\mathrm{D}_{2} \mathrm{O}, 400 \mathrm{MHz}\right) 3.63(1 \mathrm{H}, \mathrm{m}, \mathrm{H} 2), 3.66$ $\left(1 \mathrm{H}, \mathrm{dd}, J_{5,4} 5.4, J_{5,5^{\prime}} 7.0, \mathrm{H} 5\right), 3.83\left(1 \mathrm{H}, \mathrm{m}, \mathrm{H} 5^{\prime}\right), 3.87$ $\left(1 \mathrm{H}, \mathrm{d}, J_{1,1^{\prime}} 16.0, \mathrm{H} 1\right), 4.01\left(2 \mathrm{H}, \mathrm{m}, \mathrm{CH}_{2} \mathrm{~N}\right), 4.07(1 \mathrm{H}, \mathrm{d}$, $\left.J_{1^{\prime}, 1} 16.0, \mathrm{H}^{\prime}\right), 4.15\left(1 \mathrm{H}, \mathrm{t}, J_{3,4} / J_{3,2} 3.6, \mathrm{H} 3\right), 4.38(1 \mathrm{H}, \mathrm{m}$, $\mathrm{H} 4) ; \delta_{\mathrm{C}}\left(\mathrm{D}_{2} \mathrm{O}, 100.6 \mathrm{MHz}\right)$ 58.2, 58.4 $\left(\mathrm{CH}_{2} \mathrm{~N}\right.$ and $\left.\mathrm{C} 1\right), 60.4$ (C5), 74.2, 74.4 (C2 and C4), 76.6 (C3), $170.8(\mathrm{C}=\mathrm{O}) ; \mathrm{m} / \mathrm{z}$ $\left(\mathrm{ESI}^{+}\right): 192\left([\mathrm{M}+\mathrm{H}]^{+}, 15 \%\right), 214\left([\mathrm{M}+\mathrm{Na}]^{+}, 100 \%\right) ; \mathrm{HRMS}$ $\left(\mathrm{ESI}^{+}\right)$: found $214.0687\left([\mathrm{M}+\mathrm{Na}]^{+}\right) ; \mathrm{C}_{7} \mathrm{H}_{13} \mathrm{NNaO}_{5}$ requires 214.0686 .

\section{$\mathrm{N}$-Carboxymethyl-2,5-dideoxy-2,5-iminogalactitol 11}

galacto-DMDP $10(15 \mathrm{mg}, 0.09 \mathrm{mmol})$ gave the $N$-acetic acid $11(20 \mathrm{mg}, 99 \%)[\alpha]_{\mathrm{D}}^{25} 0.0\left(c 0.30, \mathrm{H}_{2} \mathrm{O}\right) ; \nu_{\max }$ (thin film): $3360(\mathrm{OH}), 3250(\mathrm{OH}), 1741(\mathrm{COO}) ; \delta_{\mathrm{H}}\left(\mathrm{D}_{2} \mathrm{O}\right.$, $400 \mathrm{MHz}$ ): $3.06\left(2 \mathrm{H}\right.$, ddd, $J_{2,1} 4.3, J_{2,3} 5.3, J_{2,1^{\prime}} 6.1, \mathrm{H} 2$ ), $3.24\left(2 \mathrm{H}, \mathrm{s}, \mathrm{CH}_{2} \mathrm{~N}\right), 3.54\left(2 \mathrm{H}, \mathrm{dd}, J_{1,2} 4.3, J_{1,1^{\prime}} 11.3, \mathrm{H} 1\right)$, $3.61\left(2 \mathrm{H}, \mathrm{dd}, J_{1^{\prime}, 2} 6.1, J_{1^{\prime}, 1} 11.3, \mathrm{H} 1^{\prime}\right), 4.25\left(2 \mathrm{H}, \mathrm{d}, J_{3,2} 5.3\right.$, $\mathrm{H} 3) ; \delta_{\mathrm{C}}\left(\mathrm{D}_{2} \mathrm{O}, 100.6 \mathrm{MHz}\right): 57.0\left(\mathrm{CH}_{2} \mathrm{~N}\right), 60.2(\mathrm{C} 1), 66.4$ (C2), $72.3(\mathrm{C} 3), 180.4(\mathrm{C}=\mathrm{O}) ; \mathrm{m} / \mathrm{z}\left(\mathrm{ESI}^{+}\right): 222\left([\mathrm{M}+\mathrm{H}]^{+}\right.$, $100 \%), 244\left([\mathrm{M}+\mathrm{Na}]^{+}, 35 \%\right) ;\left(\mathrm{ESI}^{-}\right): 220\left([\mathrm{M}-\mathrm{H}]^{-}, 100 \%\right)$. HRMS $\left(\mathrm{ESI}^{+}\right)$: found $220.0830\left([\mathrm{M}-\mathrm{H}]^{-}\right) ; \mathrm{C}_{8} \mathrm{H}_{14} \mathrm{NO}_{6}$ requires 220.0827 .

\section{General procedure for $\mathbf{N}$-propionic acids}

tert-Butylacrylate (10 eq) was added to a stirred solution of the corresponding iminosugar or hydroxylated proline (1 eq) in methanol $(10 \mathrm{mg} / \mathrm{mL})$. The mixture was stirred at $50{ }^{\circ} \mathrm{C}$ for $48 \mathrm{~h}$, after which the reaction was shown to be complete by mass spectrometry. The mixture was concentrated in vacuo to afford the crude ester, which was dissolved in a mixture of trifluoroacetic acid $(0.5 \mathrm{~mL})$ and water $(0.5 \mathrm{~mL})$ and stirred at room temperature. After $48 \mathrm{~h}$, the solvents were removed in vacuo. The remaining residue was loaded onto a Dowex ion-exchange resin $\left(50 \mathrm{WX} 8, \mathrm{H}^{+}\right)$. The column was flushed with water and then eluted with $2 \mathrm{M}$ aqueous 
ammonia. The ammoniacal fraction was concentrated in vacuo to afford the title compounds.

\section{$\mathrm{N}$-(2-Carboxyethyl)-2,5-dideoxy-2,5-imino-D-manni- tol 6}

DMDP 1 (33 mg, $0.20 \mathrm{mmol}$ ) gave DMDP propionic acid $6(48 \mathrm{mg}, 100 \%)[\alpha]_{\mathrm{D}}^{25}-25.2$ (c 0.1, methanol); $\nu_{\max }$ (thin film) $3229(\mathrm{OH}), 1577,1390(\mathrm{COO}) ; \delta_{\mathrm{H}}\left(\mathrm{D}_{2} \mathrm{O}, 400 \mathrm{MHz}\right)$ $2.56\left(2 \mathrm{H}, \mathrm{m}, \mathrm{CH}_{2} \mathrm{COO}\right), 3.45\left(2 \mathrm{H}, \mathrm{t}, J 6.4, \mathrm{CH}_{2} \mathrm{~N}\right), 3.59$ ( $2 \mathrm{H}, \mathrm{bs}, \mathrm{H} 2$ and $\mathrm{H} 5), 3.93$ (4H, d, $J_{1,2} / J_{6,5} 3.2, \mathrm{H} 1$ and $\mathrm{H} 6$ ), $4.13\left(2 \mathrm{H}, \mathrm{d}, J_{3,2} / J_{4,5} 3.2, \mathrm{H} 3\right.$ and $\left.\mathrm{H} 4\right) ; \delta_{\mathrm{C}}\left(\mathrm{D}_{2} \mathrm{O}, 100.6 \mathrm{MHz}\right)$ $31.7\left(\mathrm{CH}_{2} \mathrm{COO}\right), 46.7\left(\mathrm{CH}_{2} \mathrm{~N}\right), 57.5(\mathrm{C} 1$ and $\mathrm{C} 6), 70.4(\mathrm{C} 2$ and $\mathrm{C} 5), 76.3(\mathrm{C} 3$ and $\mathrm{C} 4), 179.1(\mathrm{C}=\mathrm{O}) ; \mathrm{m} / \mathrm{z}\left(\mathrm{ESI}^{+}\right): 236$ $\left([\mathrm{M}+\mathrm{H}]^{+}, 100 \%\right), 258\left([\mathrm{M}+\mathrm{Na}]^{+}, 89 \%\right), 493\left([2 \mathrm{M}+\mathrm{Na}]^{+}\right.$, $100 \%)$; HRMS $\left(\mathrm{ESI}^{+}\right)$: found $236.1131\left([\mathrm{M}+\mathrm{H}]^{+}\right)$; $\mathrm{C}_{9} \mathrm{H}_{18} \mathrm{NO}_{6}$ requires 236.1129 .

\section{$\mathrm{N}$-(2-Carboxyethyl)-1,4-dideoxy-1,4-imino-D-arabi- nitol 9}

DAB $1(9 \mathrm{mg}, 0.07 \mathrm{mmol}$ ) gave DAB propionic acid 9 (14 mg, 100\%) $[\alpha]_{\mathrm{D}}^{25}+12.7$ (c 0.43, water); $\nu_{\max }$ (thin film) $3239(\mathrm{OH}), 1579,1388(\mathrm{COO}) ; \delta_{\mathrm{H}}\left(\mathrm{D}_{2} \mathrm{O}, 400 \mathrm{MHz}\right) 2.70$ $\left(2 \mathrm{H}, \mathrm{m}, \mathrm{CH}_{2} \mathrm{COO}\right), 3.40\left(1 \mathrm{H}, \mathrm{m}, \mathrm{CH}_{2} \mathrm{~N}\right), 3.54(2 \mathrm{H}, \mathrm{m}, \mathrm{H} 2$ and $\mathrm{H} 5), 3.72\left(2 \mathrm{H}, \mathrm{m}, \mathrm{H}^{\prime}\right.$ and $\left.\mathrm{CH}_{2} \mathrm{~N}\right), 3.99(2 \mathrm{H}, \mathrm{m}, \mathrm{H} 1$ and $\left.\mathrm{H} 1^{\prime}\right), 4.16(1 \mathrm{H}, \mathrm{m}, \mathrm{H} 3), 4.37(1 \mathrm{H}, \mathrm{m}, \mathrm{H} 4) ; \delta_{\mathrm{C}}\left(\mathrm{D}_{2} \mathrm{O}\right.$, $100.6 \mathrm{MHz}) 31.9\left(\mathrm{CH}_{2} \mathrm{COO}\right), 53.3\left(\mathrm{CH}_{2} \mathrm{~N}\right), 58.7(\mathrm{C} 1$ and C5), 74.2, 75.5, $76.6(\mathrm{C} 2, \mathrm{C} 3$, and $\mathrm{C} 4), 178.0(\mathrm{C}=\mathrm{O})$; $\mathrm{m} / \mathrm{z}\left(\mathrm{ESI}^{+}\right): 206\left([\mathrm{M}+\mathrm{H}]^{+}, 92 \%\right), 228\left([\mathrm{M}+\mathrm{Na}]^{+}, 100 \%\right)$, $433\left([2 \mathrm{M}+\mathrm{Na}]^{+}, 46 \%\right)$; HRMS $\left(\mathrm{ESI}^{+}\right)$: found 228.0847 $\left([\mathrm{M}+\mathrm{Na}]^{+}\right) ; \mathrm{C}_{8} \mathrm{H}_{15} \mathrm{NNaO}_{5}$ requires 228.0842 .

\section{$\mathrm{N}$-(2-Carboxyethyl)-2,5-dideoxy-2,5-iminogalactitol 12}

galacto-DMDP $10(21 \mathrm{mg}, 0.13 \mathrm{mmol})$ gave the propionic acid $12(25 \mathrm{mg}, 83 \%)[\alpha]_{\mathrm{D}}^{25} 0.0\left(c 1.1, \mathrm{H}_{2} \mathrm{O}\right) ; \nu_{\max }$ (thin film): $3451(\mathrm{OH}), 3343(\mathrm{OH}), 1738(\mathrm{COO}) ; \delta_{\mathrm{H}}\left(\mathrm{D}_{2} \mathrm{O}, 400 \mathrm{MHz}\right)$ : 2.51-2.63 (2H, m, CH$\left.H_{2} \mathrm{COO}\right), 3.00\left(2 \mathrm{H}, \mathrm{a}-\mathrm{q}, J_{2,1} / J_{2,1} / J_{2,3}\right.$ 5.1, H2), $3.25\left(2 \mathrm{H}, \mathrm{a}-\mathrm{t}, J 6.0, \mathrm{CH}_{2} \mathrm{~N}\right), 3.48\left(2 \mathrm{H}, \mathrm{dd}, J_{1,2} 4.5\right.$, $J_{1,1^{\prime}}$ 11.2, H1), $3.55\left(2 \mathrm{H}, \mathrm{dd}, J_{1^{\prime}, 2} 5.8, J_{1^{\prime}, 1} 11.2, \mathrm{H} 1^{\prime}\right), 4.20$ $\left(2 \mathrm{H}, \mathrm{d}, J_{3,2} 5.0, \mathrm{H} 3\right) ; \delta_{\mathrm{C}}\left(\mathrm{D}_{2} \mathrm{O}, 100.6 \mathrm{MHz}\right): 33.2\left(\mathrm{CH}_{2} \mathrm{COO}\right)$, $48.5\left(\mathrm{CH}_{2} \mathrm{~N}\right), 60.1(\mathrm{C} 1), 66.3(\mathrm{C} 2), 72.2(\mathrm{C} 5), 180.4(\mathrm{C}=\mathrm{O})$; $\mathrm{m} / \mathrm{z}\left(\mathrm{ESI}^{+}\right): 236\left([\mathrm{M}+\mathrm{H}]^{+}, 100 \%\right), 258\left(\left[\mathrm{M}+\mathrm{Na}^{+}\right], 85 \%\right)$; $\left(\mathrm{ESI}^{-}\right): 234\left([\mathrm{M}-\mathrm{H}]^{-}, 100 \%\right)$. HRMS $\left(\mathrm{ESI}^{-}\right)$: found $234.0990[\mathrm{M}-\mathrm{H}]^{-} ; \mathrm{C}_{9} \mathrm{H}_{16} \mathrm{NO}_{6}$ requires 234.0983.
$\mathrm{N}$-(2-Carboxyethyl)-2,5-dideoxy-2,5-imino-D-mannonic acid 15

tert-Butylacrylate $(0.25 \mathrm{~mL}, 1.7 \mathrm{mmol})$ and triethylamine $(0.04 \mathrm{~mL}, 0.29 \mathrm{mmol})$ were added to a stirred solution of the iminomannonic acid 13 (30 mg, $0.17 \mathrm{mmol})$ in methanol $(1.5 \mathrm{~mL})$. The mixture was stirred at $50{ }^{\circ} \mathrm{C}$ for $48 \mathrm{~h}$ and then concentrated in vacuo. The crude was redissolved in a mixture of trifluoroacetic acid $(1.5 \mathrm{~mL})$ and water $(1.5 \mathrm{~mL})$, and the resulting solution was stirred at room temperature. After $48 \mathrm{~h}$, the reaction was judged to be complete by mass spectrometry. The solvents were removed in vacuo and the remaining residue was loaded onto an Amberlite CG-400 strongly basic ion-exchange resin. The column was flushed with water and then eluted with $2 \mathrm{M}$ acetic acid. The acidic fraction was concentrated in vacuo to afford the propionic acid $15(42 \mathrm{mg}, 100 \%)$. $[\alpha]_{\mathrm{D}}^{25}-6.7(c 0.75$, water $) ; \nu_{\max }$ (thin film) $3262(\mathrm{OH})$, $1711,1621(\mathrm{COO}) ; \delta_{\mathrm{H}}\left(\mathrm{D}_{2} \mathrm{O}, 400 \mathrm{MHz}\right) 2.90(2 \mathrm{H}, \mathrm{m}$, $\left.\mathrm{CH}_{2} \mathrm{COO}\right), 3.64\left(1 \mathrm{H}, \mathrm{m}, \mathrm{CH}_{2} \mathrm{~N}\right), 3.86\left(1 \mathrm{H}, \mathrm{m}, \mathrm{CH}_{2} \mathrm{~N}\right), 4.02$ (1H, m, H5), 4.09 (2H, m, H6), $4.13\left(1 \mathrm{H}, \mathrm{d}, J_{2,3} 2.8, \mathrm{H} 2\right)$, $4.28\left(1 \mathrm{H}, \mathrm{t}, J_{4,5} / J_{4,3} 2.8, \mathrm{H} 4\right), 4.33\left(1 \mathrm{H}, \mathrm{d}, J_{3,2} / J_{3,4} 2.8, \mathrm{H} 3\right)$; $\delta_{\mathrm{C}}\left(\mathrm{D}_{2} \mathrm{O}, 100.6 \mathrm{MHz}\right) 30.3\left(\mathrm{CH}_{2} \mathrm{COO}\right), 47.3\left(\mathrm{CH}_{2} \mathrm{~N}\right), 57.2$ (C6), 72.3 (C5), 74.2 (C2), 76.8 (C4), 79.2 (C3), 170.8, $174.9(\mathrm{C}=\mathrm{O}) ; \mathrm{m} / \mathrm{z}\left(\mathrm{ESI}^{-}\right): 248\left([\mathrm{M}-\mathrm{H}]^{-}, 100 \%\right) ; \mathrm{HRMS}$ $\left(\mathrm{ESI}^{+}\right)$: found $272.0738\left([\mathrm{M}+\mathrm{Na}]^{+}\right) ; \mathrm{C}_{9} \mathrm{H}_{15} \mathrm{NNaO}_{7}$ requires 272.0741 .

\section{$\mathrm{N}$-(2-Carboxyethyl)-2,5-dideoxy-2,5-imino-D-lyxonic acid 18}

The trans,trans-dihydroxyproline $16(33 \mathrm{mg}, 0.22 \mathrm{mmol})$ gave the propionic acid $\mathbf{1 8}(47 \mathrm{mg}, 100 \%)$ by the same procedure used for the synthesis of 15. $[\alpha]_{\mathrm{D}}^{25}-2.3(c 0.48$, water); $\nu_{\max }$ (thin film): $3367(\mathrm{OH}), 1623,1707(\mathrm{COO}) ; \delta_{\mathrm{H}}$ ( $\mathrm{D}_{2} \mathrm{O}, 400 \mathrm{MHz}, \mathrm{HCl}$ Salt): 2.77-2.85 (2H, m, $\left.\mathrm{CH}_{2} \mathrm{COO}\right)$, 3.51-3.54 $\left(3 \mathrm{H}, \mathrm{m}, \mathrm{CH}_{2} \mathrm{~N}\right.$ and $\left.\mathrm{H} 5\right), 3.77\left(1 \mathrm{H}, \mathrm{d}, \mathrm{H} 5{ }^{\prime}\right.$, $\left.J_{5^{\prime}, 5} 12.1\right), 4.04(1 \mathrm{H}, \mathrm{s}, \mathrm{H} 2), 4.24(1 \mathrm{H}, \mathrm{s}, \mathrm{H} 4), 4.43(1 \mathrm{H}, \mathrm{s}$, $\mathrm{H} 3) ; \delta_{\mathrm{C}}\left(\mathrm{D}_{2} \mathrm{O}, 100.6 \mathrm{MHz}, \mathrm{HCl}\right.$ salt): $30.3\left(\mathrm{CH}_{2} \mathrm{COO}\right), 52.7$ $\left(\mathrm{CH}_{2} \mathrm{~N}\right), 60.4(\mathrm{C} 5), 74.4(\mathrm{C} 4), 76.2(\mathrm{C} 2), 79.1(\mathrm{C} 3), 174.7$, $177.3(\mathrm{C}=\mathrm{O}) ; \mathrm{m} / \mathrm{z}\left(\mathrm{ESI}^{+}\right): 220\left([\mathrm{M}+\mathrm{H}]^{+}, 100 \%\right)$; HRMS $\left(\mathrm{ESI}^{+}\right)$: found $220.0806[\mathrm{M}+\mathrm{H}]^{+} ; \mathrm{C}_{8} \mathrm{H}_{14} \mathrm{NO}_{6}$ requires 220.0816 .

\section{$\mathrm{N}$-(2-carboxyethyl)-1,5-dideoxy-1,5-imino-D-glucitol (DNJ-propionic acid) 20}

tert-Butyl acrylate $(0.15 \mathrm{~mL}, 1.04 \mathrm{mmol})$ was added to a stirred solution of DNJ $2(17 \mathrm{mg}, 0.1 \mathrm{mmol})$ in methanol $(1 \mathrm{~mL})$. The mixture was stirred at $50{ }^{\circ} \mathrm{C}$ for $41 \mathrm{~h}$ after which more tert-butyl acrylate $(0.15 \mathrm{~mL})$ was added. After 
a further $24 \mathrm{~h}$, the reaction mixture was concentrated in vacuo. The crude residue was re-dissolved in a mixture of trifluoroacetic acid $(1 \mathrm{~mL})$ and water $(1 \mathrm{~mL})$, and the resulting solution was stirred at rt. After $48 \mathrm{~h}$, the solvents were removed in vacuo and the remaining residue was loaded onto a Dowex ion-exchange resin $\left(50 \mathrm{WX} 8 \mathrm{H}^{+}\right)$. The column was flushed with water and then eluted with $2 \mathrm{M}$ aqueous ammonia. The ammoniacal fraction was reduced in vacuo to afford the $N$-propionic acid $\mathbf{2 0}$ as white solid $(25 \mathrm{mg}, 99 \%)$. $[\alpha]_{\mathrm{D}}^{20}$ $-8.0\left(c, 0.95\right.$ in water); $\nu_{\max }$ (thin film) $3206(\mathrm{OH}), 1563$ (COO); m.p. 196-198 ${ }^{\circ} \mathrm{C} ; \delta_{\mathrm{H}}\left(\mathrm{D}_{2} \mathrm{O}, 400 \mathrm{MHz}\right) 2.52(\mathrm{~m}, 2 \mathrm{H}$, $\left.\mathrm{CH}_{2} \mathrm{COO}\right), 2.65$ (t, $\left.J_{\text {gem }}=J_{1,2}=11.6,1 \mathrm{H}, \mathrm{H}-1\right), 2.71(\mathrm{~m}, 1 \mathrm{H}$, $\mathrm{H}-5), 3.12\left(\mathrm{~m}, 1 \mathrm{H}, \mathrm{CH}_{2} \mathrm{~N}\right), 3.27\left(\mathrm{~d}, J_{\mathrm{gem}}=11.6, J_{1^{\prime}, 2}=4.8\right.$, $\left.1 \mathrm{H}, \mathrm{H}-1^{\prime}\right), 3.33\left(\mathrm{~m}, 1 \mathrm{H}, \mathrm{CH}_{2} \mathrm{~N}\right), 3.38\left(\mathrm{t}, J_{3,2}=J_{3,4}=9.4\right.$, $1 \mathrm{H}, \mathrm{H}-3), 3.53\left(\mathrm{t}, J_{4,5}=J_{4,3}=9.4,1 \mathrm{H}, \mathrm{H}-4\right), 3.66(\mathrm{ddd}$, $\left.J_{2,1^{\prime}}=4.8, J_{2,3}=9.4, J_{2,1}=11.6,1 \mathrm{H}, \mathrm{H}-2\right), 3.95\left(\mathrm{dd}, J_{6,5}=2.4\right.$, $\left.J_{6,6^{\prime}}=13.5,1 \mathrm{H}, \mathrm{H}-6\right), 4.00\left(\mathrm{dd}, J_{6^{\prime}, 5}=2.7, J_{6^{\prime}, 6}=13.5,1 \mathrm{H}\right.$, $\left.\mathrm{H}-6^{\prime}\right) ; \delta_{\mathrm{C}}\left(\mathrm{D}_{2} \mathrm{O}, 100.6 \mathrm{MHz}\right) 31.9\left(\mathrm{CH}_{2} \mathrm{COO}\right), 49.6\left(\mathrm{CH}_{2} \mathrm{~N}\right)$, 54.6 (C-1), 56.2 (C-6), 65.6 (C-5), 68.1 (C-2), 69.3 (C-4), $77.7(\mathrm{C}-3), 180.2(\mathrm{C}=\mathrm{O}) ; \mathrm{m} / z\left(\mathrm{ESI}^{+}\right): 236\left([\mathrm{M}+\mathrm{H}]^{+}, 100 \%\right)$, $258\left([\mathrm{M}+\mathrm{Na}]^{+}, 42 \%\right), 493\left([2 \mathrm{M}+\mathrm{Na}]^{+}, 25 \%\right) ; \mathrm{HRMS}$ $\left(\mathrm{ESI}^{+}\right)$: found $236.1137\left([\mathrm{M}+\mathrm{H}]^{+}\right) ; \mathrm{C}_{9} \mathrm{H}_{18} \mathrm{NO}_{6}{ }^{+}$requires 236.1129 .

\section{Glycosidase inhibition (Kato et al. 2015)}

The enzymes $\alpha$-glucosidase (from rice, yeast, and A. niger), $\beta$-glucosidase (from almond, bovine liver, and A. niger), $\alpha$-galactosidase (from coffee beans), $\beta$-galactosidase (from bovine liver), $\alpha$-mannosidase (from jack bean), $\beta$-mannosidase (from snail), $\alpha$-L-rhamnosidase (from Penicillium decumbens), $\alpha$-L-fucosidase (from bovine kidney), $\beta$-glucuronidases (from E. coli and bovine liver), amyloglucosidase (A. niger, and Rhizopus sp.), p-nitrophenyl glycosides, and various disaccharides were purchased from Sigma-Aldrich Co. Brush border membranes were prepared from the rat small intestine (Kessler et al. 1978), and were assayed at pH 6.8 for rat intestinal maltase using maltose. For rat intestinal maltase activities, the reaction mixture contained $25 \mathrm{mM}$ maltose and the appropriate amount of enzyme, and the incubations were performed for $10 \mathrm{~min}$ at $37^{\circ} \mathrm{C}$. The reaction was stopped by heating at $100{ }^{\circ} \mathrm{C}$ for $3 \mathrm{~min}$. After centrifugation $(600 \mathrm{~g} ; 10 \mathrm{~min})$, the resulting reaction mixture were added to the Glucose CII-test Wako (Wako Pure Chemical Ind., Osaka, Japan). The absorbance at $505 \mathrm{~nm}$ was measured to determine the amount of the released D-glucose. Other glycosidase activities were determined using an appropriate $p$-nitrophenyl glycoside as substrate at the optimum $\mathrm{pH}$ of each enzyme. The reaction mixture contained $2 \mathrm{mM}$ of the substrate and the appropriate amount of enzyme. The reaction was stopped by adding $400 \mathrm{mM} \mathrm{Na} \mathrm{CO}_{3}$. The released $p$-nitrophenol was measured spectrometrically at $400 \mathrm{~nm}$.

\section{Conclusions}

Glycosides from leaves of $S$. rebaudiana are widely used as low calorie sweeteners (Samuel et al. 2018). Other beneficial properties from Stevia extracts have been noted (Chatsudthipong and Muanprasat 2009; Zangeneh et al. 2017); DMDP 1 was shown to be the major iminosugar in Stevia together with smaller quantities of the DMDP acetic acid $\mathbf{5}$. Although such polyhydroxylated amino acids are difficult to isolate, they may readily be obtained from unprotected pyrrolidine iminosugars with aqueous glyoxal as the corresponding $\mathrm{N}$-acetic acids and from both pyrrolidine and piperidine iminosugars and of polyhydroxylated prolines with tert-butyl acrylate as the $N$-propionic acids. The syntheses will allow the easy identification of this new class of amino acid in plant extracts and provide pure sample for biological evaluation. The potent $\beta$-galactosidase inhibition by DMDP 1 was replaced by potent $\alpha$-galactosidase inhibition by DMDP $N$-acetic 5 and propionic $\mathbf{6}$ acids; in contrast, galacto-DMDP $\mathbf{1 0}$ and both its acetic $\mathbf{1 1}$ and propionic $\mathbf{1 2}$ acids are $\alpha$-galactosidase inhibitors.

Acknowledgements This work was supported by Fundación Ramón Areces (RFM), a Grant-in-Aid for Scientific Research (C) from the Japanese Society for the Promotion of Science (JSPS KAKENHI Grant number JP17K08362) (AK).

\section{Compliance with ethical standards}

Conflict of interest The authors declare that there are no conflicts of interest.

Research involving human participants and/or animals This article does not contain any studies with human participants or animals performed by any of the authors.

Open Access This article is distributed under the terms of the Creative Commons Attribution 4.0 International License (http://creativeco mmons.org/licenses/by/4.0/), which permits unrestricted use, distribution, and reproduction in any medium, provided you give appropriate credit to the original author(s) and the source, provide a link to the Creative Commons license, and indicate if changes were made.

\section{References}

Asano N, Kizu H, Oseki K, Tomioka E, Matsui K, Okamoto M, Baba M (1995) N-alkylated nitrogen-in-the-ring sugars: conformational basis of inhibition of glycosidases and HIV-1 replication. J Med Chem 38:2349-2356

Asano N, Nash RJ, Molyneux RJ, Fleet GWJ (2000) Nitrogen-in-thering sugar mimetics: natural occurrence, biological activity and prospects for therapeutic application. Tetrahedron 11:1645-1680

Ayers BA, Ngo N, Jenkinson SF, Martínez RF, Shimada Y, Adachi I, Weymouth-Wilson AC, Kato A, Fleet GWJ (2012) Glycosidase inhibition by all ten stereoisomeric 2,5-dideoxy-2,5-iminohexitols 
prepared from the enantiomers of glucuronolactone. J Org Chem 77:7777-7792

Bell EA (1976) 'Uncommon' amino acids in plants. FEBS Lett 64:29-35

Best D, Wang C, Weymouth-Wilson AC, Clarkson RA, Wilson FX, Nash RJ, Miyauchi S, Kato A, Fleet GWJ (2010) Looking glass inhibitors: scalable syntheses of DNJ, DMDP and (3R)-3-hydroxy-L-bulgecinine from D-glucuronolactone and of L-DNJ, L-DMDP and (3S)-3-hydroxy-D-bulgecinine from L-glucuronolactone. DMDP inhibits $\beta$-glucosidases and $\beta$-galactosidases whereas L-DMDP is a potent and specific inhibitor of $\alpha$-glucosidases. Tetrahedron: Asymmetry 21:311-319

Booth KV, Jenkinson SF, Watkin DJ, Sharp H, Jones PW, Nash RJ, Fleet GWJ (2007) $(2 S, 3 R, 4 R, 5 S)-3,4,5$-Trihydroxypipecolic acid dihydrate [(2S,3R,4R,5S)-3,4,5-Trihydroxypiperidine-2-carboxylic acid dihydrate]. Acta Crystallogr E63:o3783-03784

Chatsudthipong V, Muanprasat C (2009) Stevioside and related compounds: therapeutic benefits beyond sweetness. Pharmacol Ther 121:41-54

di Bello IC, Dorling P, Fellows L, Winchester B (1984) Specific inhibition of human $\beta$-D-glucuronidase and $\alpha$-L-iduronidase by a trihydroxy pipecolic acid of plant origin. FEBS Lett 176:61-64

Edgeley DS, Martínez RF, Jenkinson SF, Nash RJ, Fleet GWJ, Thompson AL (2012) $N$-(2-Carboxyethyl)-2,5-dideoxy-2,5-imino-D-mannonic acid [ $(2 S, 3 R, 4 R, 5 R)-1$-(2-carboxyethyl)-3,4-dihydroxy-5(hydroxymethyl)proline]. Acta Crystallogr Sect E 68:2865-2866

Farfán N, Cuéllar L, Aceves JM, Contreras R (1987) High-yield syntheses of $N$-(2-hydroxyethyl)- $N$-alkylglycine derivatives by reaction of ethanolamines with glyoxal. Synthesis 10:927-929

Fleet GWJ, Witty DR (1990) Synthesis of homochiral $\beta$-hydroxy$\alpha$-amino acids $[(2 \mathrm{~S}, 3 R .4 R)-3,4$-dihydroxyproline and (2S,3R.4R)-3,4-dihydroxypipecolic acid] and of 1,4-dideoxy1,4-imino-D-arabinitol [DAB1] and fagomine [1,5-imino-1,2,5trideoxy-D-arabino-hexitol]. Tetrahedron 1:119-136

Fleet GWJ, Bashyal BP, Chow H-F (1986) Enantiospecific syntheses of $2 S, 3 R, 4 R, 5 S$-trihydroxypipecolic acid, $2 R, 3 R, 4 R, 5 S$-trihydroxypipecolic acid, $2 S, 4 S, 5 S$-dihydroxypipecolic acid, and bulgecinine from D-glucuronolactone. Tetrahedron Lett 27:3205-3208

Fleet GWJ, Bashyal BP, Chow H-F, Fellows LE (1987) The synthesis of polyhydroxylated amino acids from glucuronolactone: enantiospecific syntheses of $2 S, 3 R, 4 R, 5 S$-trihydroxypipecolic acid, $2 R, 3 R, 4 R, 5 S$-trihydroxypipecolic acid and $2 R, 3 R, 4 R$-dihydroxyproline. Tetrahedron 43:415-422

Gallagher A, Yu H (2014) Morus extracts rich in $N$-acids of imino sugars and or pipecolic acids. U.S. Patent US20140328950A1

Kato A, Zhang ZL, Wang HY, Jia YM, Yu C-Y, Kinami K, Hirokami Y, Tsuji Y, Adachi I, Nash RJ, Fleet GWJ, Koseki J, Nakagome I, Hirono SJ (2015) Design and synthesis of labystegines, hybrid iminosugars from LAB and calystegine, as inhibitors of intestinal $\alpha$-glucosidases: binding conformation and interaction for $\mathrm{ntSI}$. Org Chem 80:4501-4515

Kessler M, Acuto O, Strelli C, Murer H, Semenza GAA (1978) A modified procedure for the rapid preparation of efficiently transporting vesicles from small intestinal brush border membranes. Their use in investigating some properties of D-glucose and choline transport systems. Biochem Biophys Acta 506:136-154

Manning KS, Lynn DG, Shabanowitx J, Fellows LE, Singh M, Schrire BD (1985) A glucuronidase inhibitor from the seeds of Baphia racemosa: application of fast atom bombardment coupled with collision activated dissociation in natural product structure assignment. J Chem Soc Chem Commun, 127-129

Michalik A, Hollinshead J, Jones L, Fleet GWJ, Yu C-Y, Hu X-G, van Well R, Horne G, Wilson FX, Nash RJ (2010) Steviamine, a new class of indolizidine alkaloid from Stevia rebaudiana. Phytochem Lett 3:136-138

Nash RJ, Braganca RM, Newbold CJ, Morales ER (2018) Methods and compositions for improving feed outcomes. GB2557247

Pereira ACdeS, Kaplan MAC, Maia JGS, Gottlieb OR, Nash RJ, Fleet GWJ, Pearce L, Watkin DJ, Scofield AM (1991) Isolation of 7a-epialexaflorine from leaves of Alexa grandiflora; a unique pyrrolizidine amino acid with a carboxylic acid substituent at C-3 . Tetrahedron 47:5637-5640

Ramessur KT, Greenwell P, Nash RJ, Dwek MV (2010) Breast cancer invasion is mediated by beta- $N$-acetylglucosaminidase (betaNAG) and associated with a dysregulation in the secretory pathway of cancer cells. Br J Biomed Sci 67:189-196

Risseeuw MDP, Overhand M, Fleet GWJ, Simone MI (2007) A compendium of sugar amino acids (SAA): scaffolds, peptide- and glyco-mimetics. Tetrahedron 18:2001-2010

Risseeuw MDP, Overhand M, Fleet GWJ, Simone MI (2013) A compendium of cyclic sugar amino acids and their carbocyclic and heterocyclic nitrogen analogues. Amino Acids 45:613-689

Samuel P, Ayoob KT, Magnuson BA, Wölwer-Rieck U, Jeppesen PB, Rogers PJ, Rowland I, Mathews R (2018) Stevia leaf to Stevia sweetener: exploring its science, benefits, and future potential. J Nutr 148:1186S-1205S

Thompson AL, Michalik A, Nash RJ, Wilson FX, van Well R, Johnson P, Fleet GWJ, Yu C-Y, Hu X-G, Cooper RI, Watkin DJ (2009) Steviamine, a new class of indolizidine alkaloid $[(1 R, 2 S, 3 R, 5 R, 8 a R)$ 3-(hydroxymethyl)-5- methyloctahydroindolizine-1,2-diol hydrobromide]. Acta Crystallogr E 65:02904

Watson AA, Fleet GWJ, Asano N, Molyneux RJ, Nash RJ (2001) Polyhydroxylated alkaloids-natural occurrence and therapeutic applications. Phytochemistry 56:265-295

Wilson FX, Nash RJ, Horne G, Storer R, Tinsley JM, Roach AG (2010) Treatment of energy utilization diseases. WO2010049678

Zangeneh MM, Najafi F, Tahvilian R, Salmani S, Haghnazari L, Zangeneh A, Moradi R (2017) Ethnomedicinal plants: in vitro antibacterial effects of ethanolic extract of Stevia rebaudiana. Int J Ayurveda Pharm Chem 6:251-259

Publisher's Note Springer Nature remains neutral with regard to jurisdictional claims in published maps and institutional affiliations. 